\title{
A novel bacterium involved in the degradation of 2-methylindole isolated from sediment of Inner Deep Bay of Hong Kong
}

\section{Karen Choi-Wan Yip and Ji-Dong Gu*}

Laboratory of Environmental Microbiology and Toxicology, School of Biological Sciences, Faculty of Science, The University of Hong Kong, Pokfulam Road, Hong Kong SAR, People’s Republic of China

\begin{abstract}
A bacterial strain, designated as MPKc, was isolated from the mudflat sediment of Mai Po Inner Deep Bay of Hong Kong Mai Po Nature Reserve by enrichment culturing with 2-methylindole as the sole source of carbon and energy. The microorganism was a Gram-negative, rod-shaped $(0.4-0.6 \mu \mathrm{m} \times 1.0-2.2 \mu \mathrm{m})$ and aerobic bacterium. Phylogenetic analysis based on the 16S rRNA gene sequences indicated that strain MPKc should be assigned as a novel bacterium, at least, at the species level. The 16S rDNA sequence most similiar to that of strain MPKc was Azoarcus evansii (94\%) from available 16S rDNA sequences of the GenBank, indicating that strain MPKc was a member of the $\beta$-subclass of the Proteobacteria. Biochemical tests showed that strain MPKc was able to reduce nitrate to nitrogen. Carbon sources utilized by this strain included adipic acid, malate, citrate and phenylacetic acid although it only grew weakly on glucose, arabinose, mannose, mannitol, $N$-acetyl-glucosamine, maltose and gluconate. Strain MPKc showed no growth on capric acid. Its optimal growth occurred at $30^{\circ} \mathrm{C}, \mathrm{pH} 6.5-7.5$ and salinity 5-10\%. Strain MPKc was capable of degrading $80 \mu \mathrm{M}$ 2-methylindole in 7 days under aerobic conditions. The possible chemical pathway for 2-methylindole degradation is through oxidation at 3-position or/and 2-position of the pyrrole ring.
\end{abstract}

Keywords: 3-methylindole, metabolism, Mai Po Nature Reserve, culturability

*Correspondence to: Ji-Dong Gu, School of Biological Sciences, Faculty of Science, The University of Hong Kong, Pokfulam Road, Hong Kong SAR, People’s Republic of China; Email: jdgu@hku.hk

Received: October 9, 2015; Accepted: March 8, 2016; Published Online: April 8, 2016

Citation: Yip K C-W and Gu J-D, 2016, A novel bacterium involved in the degradation of 2-methylindole isolated from sediment of Inner Deep Bay of Hong Kong. Applied Environmental Biotechnology, vol.1(1): 52-63. http://dx.doi.org/10.26789/AEB.2016.01.008.

\section{Introduction}

$\mathrm{I}$ ndolic compounds, including indole, 1-methylindole, 2-methylindole and 3-methylindole, are nitrogenous heterocyclic aromatics. They are ubiquitous in our environment because of their common presence in coal $\operatorname{tar}^{[1]}$, cigarette smoke ${ }^{[2]}$ and animal wastes ${ }^{[3,4]}$ and also their wide usage in industries for making dyes, medicine, pesticides, agricultural chemicals and industrial solvents ${ }^{[5-7]}$. Although their toxicity has not been well documented in details, Wilkes ${ }^{[8]}$ and Ochiai et al.$^{[9]}$ have suggested that they are potentially carcinogenic, posing a serious threat to humans and animals. Ochiai et al. ${ }^{[9]}$ studied the mutagenicities of indole and its 30 derivatives, including 1-methylindole, 2-methylindole and 3-methylindole, after nitrite treatment because nitrite is taken into human body and also formed endogenously and it reacts with various compounds to yield mutagens. They found that, among 31 tested indole derivatives, 1-methylindole showed the highest mutagenicity after nitrite treatment to Salmonella typhimurium TA100. They

A novel bacterium involved in the degradation of 2-methylindole isolated from sediment of Inner Deep Bay of Hong Kong. ㄷ 2016 Karen Choi-Wan Yip and Ji-Dong Gu. This is an Open Access article distributed under the terms of the Creative Commons Attribution-NonCommercial 4.0 International License (http://creativecommons.org/licenses/by- nc/4.0/), permitting all non-commercial use, distribution, and reproduction in any medium, provided the original work is properly cited. 
also concluded that the mutagenic precursor activities of both 1-methylindole and 2-methylindole are even comparable with the mutagenicities of typical carcinogens such as benzo[a]pyrene and 3-methylcholanthrene ${ }^{[10]}$. Due to their wide presence and potential hazards in the environment, it is significant to study their fates so as to evaluate their risks in the environment. It is widely believed that bacteria play a vital role in transforming chemicals in the ecosystem and facilitating nutrient cycling. Therefore, studying their biodegradation by bacteria is essential for understanding their fates and evaluating their hazards in the environment.

Despite the great importance of studying the biodegradation of indolic compounds, information on the degradation, transformation and the fate of these chemicals, especially 1-methylindole and 2-methylindole, is fairly limited ${ }^{[7]}$. To my best knowledge, up to now, only Gu and Berry ${ }^{[11]}$, Johansen et al. ${ }^{[12]}$ and Gu et al. ${ }^{[7]}$ have studied the biodegradation of 1-methylindole and 2-methylindole. All of these studies were carried out under strictly anaerobic conditions, namely methanogenic or sulfate-reducing conditions, and none of them demonstrated that bacteria could degrade 1-methylindole or 2-methylindole. In contrast, degradation of 3-methylindole has been reported under methanogenic ${ }^{[7,11,13]}$ and sulfate-reducing conditions ${ }^{[7,12]}$.

The Mai Po and Inner Deep Bay wetland, located at the border of the north-western part of Hong Kong Special Administrative Region, People's Republic of China and of the south-western part of the Shenzhen Special Economic Zone in the Guangdong Province of China, was listed as a Wetland of International Importance under Ramsar Conservation in September 1995. It is the largest remaining wetland in Hong Kong and plays a very important role in supporting a wide range of wild life including migratory birds and local important species ${ }^{[14]}$. It is not only an important breeding, feeding, resting and refuelling station in winter for over 250 species of birds ${ }^{[15]}$ including 12 rare and threatened species of birds ${ }^{[16]}$, but also supports a diverse community of local flora and fauna, including over a dozen endemic invertebrate species ${ }^{[14,15]}$. In recent years, the Ramsar site especially the mudflat of the Inner Deep Bay is subjected to the increasing pollution pressure from the rapid economic development on both sides of the Shenzhen River and the increasing pollution loads from the Pearl River, the Shenzhen River, the Yuen Long Creek and the Kam Tin River ${ }^{[17,18]}$.

Recently, environmental Vibrio species have been isolated and identified from this area readily and the isolates showed various characteristics in responding to environmental conditions as recently tested in this laboratory ${ }^{[19-21]}$. In addition, these bacteria have a frequency of $8 \%$ bearing plasmids, implicating for the resistance to a range of chemicals and other unknown biological function ${ }^{[22]}$. Due to the constant discharge from the rivers, the mudflat sediment of Inner Deep Bay may harbour different groups of pollutant-degrading microorganisms as demonstrated with the endocrine-disrupting phthalate esters ${ }^{[23-26]}$. Therefore, the sediment of the mudflat of Inner Deep Bay was chosen to be the inoculum in this study. The objectives of this study were to isolate the 2-methylindole-degrading bacteria from the mudflat sediment of Inner Deep Bay, and to characterize the isolated bacterium on the basis of morphology, physiology and biochemistry.

\section{Materials and Methods}

\subsection{Enrichment, Isolation, Purification and Pre- servation of Microorganisms}

The microorganism was isolated with enrichment culturing technique using the sediment from the mudflat of Mai Po Inner Deep Bay of Hong Kong SAR as an inoculum and 2-methylindole as the sole source of carbon and energy. The mineral salts medium (MSM) used for the initial enrichment culture and several successive transfers consisted of: $0.8 \mathrm{~g} / \mathrm{L} \mathrm{K}_{2} \mathrm{HPO}_{4} ; 0.2 \mathrm{~g} / \mathrm{L}$ $\mathrm{KH}_{2} \mathrm{PO}_{4} ; 1 \mathrm{~g} / \mathrm{L}\left(\mathrm{NH}_{4}\right)_{2} \mathrm{SO}_{4} ; 0.05 \mathrm{~g} / \mathrm{L} \mathrm{CaCl} 2 ; 0.5 \mathrm{~g} / \mathrm{L}$ $\mathrm{MgCl}_{2} \cdot 6 \mathrm{H} 2 \mathrm{O} ; 0.01 \mathrm{~g} / \mathrm{L} \mathrm{FeCl}_{3} \cdot 6 \mathrm{H}_{2} \mathrm{O} ; 18 \mathrm{~g} / \mathrm{L} \mathrm{NaCl}$. The medium was adjusted to $\mathrm{pH} 7.5 \pm 0.1$ with dilute $\mathrm{NaOH}$ or $\mathrm{HCl}$ and autoclaved at $120^{\circ} \mathrm{C}$, at 2 atm for 15 minutes. The initial enrichment culture was established by adding approximately $2 \mathrm{~g}$ mudflat sediment into a $250 \mathrm{~mL}$ Erlenmeyer flask containing $100 \mathrm{~mL}$ of pre-sterilized MSM and $0.1 \mathrm{~mL}$ of $100 \mathrm{mM}$ 2-methylindole (Acros Organics, USA, purity, 98\%) solution dissolved in methanol after passing through a cellulose acetate syringe filter of $0.2 \mu \mathrm{m}$ pore size (IWAKI Glass, Japan). The cultures were incubated in an incubator shaker (New Brunswick Scientific, USA) at $150 \mathrm{rpm}$ and $30 \pm 0.5^{\circ} \mathrm{C}$. The experimental setup included duplicate and one control.

During the experiment, $1 \mathrm{~mL}$ of aliquot sample was taken from each Erlenmeyer flask containing the enrichment cultures at regular time intervals (2-days) and filtered through $0.2 \mu \mathrm{m}$-pore-size-membrane syringe filter (IWAKI Glass, Japan) for analyzing the concentrations of 2-methylindole. The samples were 
quantified by external standards method on HighPerformance Liquid Chromatography (HPLC) (Agilent 1100 series, Agilent Technologies) as described below. When 2-methylindole disappeared, $5 \mathrm{~mL}$ of established microcosms was transferred from the initial enrichment culture into new Erlenmeyer flasks containing pre-sterilized MSM and 2-methylindole.

After three successive transfers were carried out, the bacterial cultures obtained were purified aseptically through spreading and streaking technique. The cultures were diluted and then inoculated on selective agar plates in duplicate. The selective agar plates consisted of MSM as described above, $0.1 \mathrm{mM}$ 2-methylindole (Acros Organics, USA), 0.1\% Nutrient broth (Oxoid Ltd., England) and 1.5\% agar (Lab M, UK). After 4 days of incubation at $30^{\circ} \mathrm{C}$, a number of tiny, well-separated, individual colonies with different morphological characteristics were developed and visible. Individual colonies with different morphological appearances were streaked onto fresh nutrient (Oxoid Ltd., England) agar (Lab M, UK) plates and incubated at $30^{\circ} \mathrm{C}$ for 3 days. The streaked plates were assessed for purity based on colony morphology and microscopic observation. Re-streaking was carried out when it is necessary to achieve pure culture of the isolated bacteria.

After the pure cultures were achieved, they were preserved using glycerol. $0.85 \mathrm{~mL}$ of pure cultures grown in nutrient broth medium (Oxoid Ltd., England) were added aseptically into sterile cryovials with 0.15 $\mathrm{mL}$ of sterilized glycerol each and were stored frozen at $-70^{\circ} \mathrm{C}$ as the Bacterial Culture Collection deposited in the Laboratory of Environmental Toxicology.

\subsection{Identification of 2-Methylindole-degrading Bacterial Isolate}

\section{Smear Preparation and Gram Staining}

The pure culture of the bacterial isolate strain MPKc capable of degrading 2-methylindole was Gram-stained $^{[27]}$. Heat-fixed culture mounts on glass slide were stained with crystal violet (primary stain) for $20 \mathrm{~s}$. After the stain was washed off with distilled water gently, the smears were covered with Gram's iodine solution for $1 \mathrm{~min}$. Afterwards, the smears were washed with 95\% ethyl alcohol for $20 \mathrm{~s}$ to decolourize the Gram-negative bacteria. Safranin, a counter-stain, was added to the smears for $20 \mathrm{~s}$ and then excess stain was washed off gently with distilled water. The Gram stained fixed mounts were observed under light microscope to determine the Gram stain reaction and assess the cellular morphological features.

\section{Physiological and Biochemical Characteristics}

The biochemical characteristics of the bacterial isolate strain MPKc were investigated using the API 20NE Multitest Kit (bioMérieux, France) following the instructions as described in the manufacturer's menu (bioMérieux 07615F, 2001). The biochemical results obtained were used to establish possible identification with similarity to those in the database by using Profile Index (bioMérieux, 1997). The detection of the enzyme cytochrome oxidase was performed with oxidase reagent (bioMérieux, France) on a filter paper. The ability of strain MPKc to reduce sulfur-containing compounds, sodium thiosulfate, to hydrogen sulfide was also tested. A tube of a semi-solid agar medium supplemented with $0.02 \%$ sodium thiosulfate and $0.015 \%$ ferrous sulfate ${ }^{[28]}$ was inoculated with liquid culture of the strain MPKc by streaking.

\section{S rDNA Sequencing}

Total genomic DNA of the bacterium strain MPKc was extracted using DNeasy ${ }^{\circledR}$ tissue kit (Qiagen Inc., USA) following the instructions as described in the handbook of the kit. $1.5 \mathrm{~mL}$ culture of the bacterium grown in nutrient broth (Oxoid Ltd., England) incubated in an incubator shaker (New Brunswick Scientific, USA) at $150 \mathrm{rpm}$ and $30^{\circ} \mathrm{C}$ for 48 hours were centrifuged at $7500 \mathrm{rpm}$ for $10 \mathrm{~min}$ in a microcentrifuge tube. After discarding the supernatant, the pellet was re-suspended in $180 \mu \mathrm{L}$ Buffer ATL. Then, the tissue in the suspension was completely lysed with 20 $\mu \mathrm{L}$ proteinase $\mathrm{K}$ at $55^{\circ} \mathrm{C} .200 \mu \mathrm{L}$ Buffer $\mathrm{AL}$ was then mixed with the samples thoroughly by vortexing and incubated at $70^{\circ} \mathrm{C}$ for $10 \mathrm{~min}$. After mixing the sample with $200 \mu \mathrm{L}$ ethanol (96-100\%) by vortexing, the mixture was centrifuged at $8000 \mathrm{rpm}$ for $1 \mathrm{~min}$ in the DNeasy Mini Spin Column with a $2 \mathrm{~mL}$ collection tube. Afterward, the sample was centrifuged with $500 \mu \mathrm{L}$ Buffer AW1 in the column with a new $2 \mathrm{~mL}$ collection tube at $8000 \mathrm{rpm}$ for $1 \mathrm{~min}$. In order to ensure that no carryover of residual ethanol occurs, $500 \mu \mathrm{L}$ Buffer AW2 was added into the sample and centrifuged for 3 min at $14000 \mathrm{rpm}$ in the column with a new collection tube. The DNeasy Mini Spin Column was placed in a clean $1.5 \mathrm{~mL}$ microcentrifuge tube followed by direct addition of $200 \mu \mathrm{L}$ Buffer AE onto the DNeasy membrane, keeping at room temperature for $1 \mathrm{~min}$ and the centrifuging for $1 \mathrm{~min}$ at $8000 \mathrm{rpm}$ subsequently. Such step was repeated again without replacing the column 
into a new microcentrifuge tube.

After the extraction of the genomic DNA of the bacterium strain MPKc, 16S rRNA gene was amplified with the universal primers forward: pA (5'-AGAGTTTGATCCTGGCTCAG-3'; E. coli bases 8 to 27) and reverse: PC5B (5'-TACCTTGTTACGACTT-3'; E. coli bases 1507 to 1492$)^{[29]}$. Amplified reaction mixtures contained $5 \mu \mathrm{L}$ of deoxynucleoside triphosphate mixture $(20 \mathrm{mM}), 5 \mu \mathrm{L}$ of $10 \times$ Taq DNA polymerase buffer, $6 \mu \mathrm{L}$ of $\mathrm{MgCl}_{2}(25 \mathrm{mM}), 2 \mu \mathrm{L}$ of each primer $(25 \mathrm{pmol} / \mu \mathrm{L}), 3 \mu \mathrm{L}$ of DNA template $(20 \mathrm{ng} / \mu \mathrm{L}), 0.5 \mu \mathrm{L}$ of Taq polymerase $(5 \mathrm{U} / \mu \mathrm{L})$ in a final reaction volume of $50 \mu \mathrm{L}$. Polymerase Chain Reaction was conducted with a PTC-200 Peltier Thermal Cycler (MJ Research Inc., Massachusetts, USA) as follows: 2 min of the denaturation at $94^{\circ} \mathrm{C}$, followed by 30 cycles of $30 \mathrm{sec}$ at $94^{\circ} \mathrm{C}$ (denaturation), $30 \mathrm{sec}$ at $50^{\circ} \mathrm{C}$ (annealing), and $60 \mathrm{sec}$ at $72^{\circ} \mathrm{C}$ (extension), with a final extension at $72^{\circ} \mathrm{C}$ for $5 \mathrm{~min}$ after 30 cycles were completed.

The amplified product was purified using Qiagen PCR Purification kit and the $1.5 \mathrm{~kb}$ fragment was ligated into the pGEM-T Easy vector (Promega Corporation, Madison, Wisconsin, USA) by using T4 DNA ligase. The total volume of $10 \mu \mathrm{L}$ ligation mixture, containing $2 \mu \mathrm{L}$ of DNA fragment, $1 \mu \mathrm{L}$ of $50 \mathrm{ng} / \mu \mathrm{L}$ pGEM-T vector, $2 \mu \mathrm{L}$ of $5 \times$ T4 DNA buffer, $0.5 \mu \mathrm{L}$ of $3 \mathrm{U} / \mu \mathrm{L}$ T4 DNA ligase and $4.5 \mu \mathrm{L}$ of distilled water, was incubated at $16^{\circ} \mathrm{C}$ overnight. The product of ligation was then transformed into competent $E$. coli JM109 cells as described elsewhere ${ }^{[30]} .2 \mu \mathrm{L}$ of the product from ligation was mixed with $200 \mu \mathrm{L}$ of suspension of competent $E$. coli JM109 cells in a sterile microfuge tube by swirling gently and then was kept in ice for $30 \mathrm{~min}$. After kept the tube in a water bath at $42^{\circ} \mathrm{C}$ for exactly 90 seconds, the cells were chilled in an ice bath for 1-2 minutes. The culture with $800 \mu \mathrm{L}$ SOC medium (2\% Bacto-tryptone, 0.5\% Bacto-yeast extract, $0.05 \% \mathrm{NaCl}, 2.5 \mathrm{mM} \mathrm{KCl}, 10 \mathrm{mM} \mathrm{MgCl}$ and $20 \mathrm{mM}$ glucose, at $\mathrm{pH}$ 7.0) was incubated in a water bath at $37^{\circ} \mathrm{C}$ for 45 minutes to allow the bacteria to recover and to express the antibiotic resistance marker encoded by the plasmid. Then, $100 \mu \mathrm{L}$ of transformed competent cells was transferred into agar LB medium (1\% Bacto-tryptone, 0.5\% Bacto-yeast extract, 1.5\% agar and $1 \% \mathrm{NaCl}$ at $\mathrm{pH} 7.5)$ containing $100 \mu \mathrm{g} / \mathrm{mL}$ amplicillin, $40 \mu \mathrm{g} / \mathrm{mL}$ X-gal (5-bromo-4-chloror-3-indolyl- $\beta$-D-galactoside) and $40 \mu \mathrm{g} / \mathrm{mL}$ IPTG (isopropylthio- $\beta$-D-galactoside). After incubation at $37^{\circ} \mathrm{C}$ for 12 hours, the positive colonies, identified by bluewhite color selection on agar plates, were selected and grew on LB medium (1\% bacto-tryptone, $0.5 \%$ bacto-yeast extract and $1 \% \mathrm{NaCl}$ at $\mathrm{pH}$ 7.5) supplemented with $100 \mu \mathrm{g} / \mathrm{ml}$ amplicillin overnight.

The liquid culture of the positive colonies stored in a sterile microcentrifuge tube was sent to the Takara Biotechnology (Dalian) Co. Ltd. (Dalian, P.R. China) for extracting the recombinant plasmid from the cells and determining the 16S rRNA gene sequence. The inserted fragment was sequenced with an ABI Prism 377XL DNA sequencer (Perkin-Elmer Applied Biosystems, Foster City, California), initially by using pGEM-T vector specific primers, then the internal primer.

The 16S rDNA sequence was aligned with related sequences from GeneBank using BioEdit Sequence Alignment Editor (BioEdit version 5.09, Department of Microbiology, North Carolina State University, U.S.). The phylogenetic and molecular evolutionary analyses were conducted with MEGA (Molecular Evolutionary Genetic Analysis) program package, version 2.1 (http://www.megasoftware.net/) by using the neighbour-joining method ${ }^{[31]}$.

\section{Scanning and Transmission Electron Microscopy}

Culture of the strain MPKc was fix ed on a $02 \mu \mathrm{m}$ pore size polycarbonate membrane filter (Osmonics, Livemore, California) in 3\% glutaraldehyde in $0.2 \mathrm{M}$ sodium cacodylate buffer overnight. The specimens were then prepared for SEM examination following the procedures of initially washing with $0.1 \mathrm{M}$ sodium cacodylate three times for 2 min each rinse, further fixing with $1 \%$ osmium tetroxide in $0.1 \mathrm{M}$ sodium cacodylate for 8 hours, rinsing with sodium cacodylate buffer and distilled water, dehydrating with ethanol series of $40 \%$ to $80 \%$ ethanol in $10 \%$ increments and then $80 \%$ ethanol to $100 \%$ ethanol in $5 \%$ increments, critical-point drying using liquid carbon dioxide and finally coating with gold-palladium as described elsewhere ${ }^{[32]}$. The prepared samples were observed under a Leica Cambridge S440 scanning electron microscope.

The culture of strain MPKc was also prepared for TEM examination by first fixing the cell suspension in $2.5 \%$ glutaraldehyde in $0.1 \mathrm{M}$ sodium cacodylate buffer for 1 hour at $4^{\circ} \mathrm{C}$; re-suspending the cells subsequently in cacodylate with $0.1 \mathrm{M}$ sucrose and in cacodylate buffer; and then further fixing the cell pellet in $1 \%$ osmium teroxide in cacodylate buffer for 30 $\mathrm{min}$ at room temperature, followed by centrifuging the cell pellet with equal volume of $2 \%$ agar immediately 
at $2500 \mathrm{rpm}$ for $10 \mathrm{~min}$ for the producing the gel block. Afterward, the gel block cut into $1 \mathrm{~mm}$ cubes was dehydrated with ethanol series of $50 \%, 70 \%$ and $90 \%$ for 5 min each and then 3 times of $100 \%$ for $10 \mathrm{~min}$ each and 2 times of propylene oxide for 5 min each. After infiltrating the tissue blocks subsequently with the mixture of epoxy resin and propylene oxide (1:1; v:v) for 1 hour 30 min at $37^{\circ} \mathrm{C}$ and epoxy resin for 1 hour at $37^{\circ} \mathrm{C}$, the tissue blocks were embedded in epoxy resin and polymerized at $90^{\circ} \mathrm{C}$ for 2 hours. Semi-thin sections in $0.4 \mu \mathrm{m}$ thickness were cut with a Reichert ultramicrotome and stained with $0.5 \%$ toluidine blue in $1 \%$ sodium borax for 30 sec. Ultra-thin sections in $100 \mathrm{~nm}$ thickness were further cut from the semi-thin sections with the target elements confirmed with light microscope in a Reichert ultramicrotome and stained subsequently with $2 \%(\mathrm{w} / \mathrm{v})$ uranyl acetate for $20 \mathrm{~min}$ and lead citrate for $15 \mathrm{~min}$. The prepared sections were then observed under a Hitachi H-600 transmission electron microscope.

\subsection{Characterization of Bacterial Isolate}

\section{Effects of Temperature}

$100 \mathrm{~mL}$ Erlenmeyer flasks containing $50 \mathrm{~mL}$ of freshly prepared sterile nutrient broth (Oxoid Ltd., England) were inoculated with $0.1 \mathrm{~mL}$ liquid culture of strain MPKc grown in nutrient broth incubated in an incubator shaker (New Brunswick Scientific, USA) at 150 rpm and $30^{\circ} \mathrm{C}$ for 36 hours. Flasks were incubated in water-bathes with shaking (Julabo SW20, Japan) and adjustable cooling system (Julabo FT200, Japan) at $15^{\circ} \mathrm{C}$ and $22^{\circ} \mathrm{C}$ at $150 \mathrm{rpm}$ and incubator shakers (New Brunswick Scientific, USA) at $30^{\circ} \mathrm{C}$ and $40^{\circ} \mathrm{C}$ at $150 \mathrm{rpm}$. Each temperature treatment was in duplicate. Flasks containing non-inoculated sterile nutrient broth were used as blank controls. During the incubation, optical density was measured at $600 \mathrm{~nm}\left(\mathrm{OD}_{600}\right)$ spectrophotometrically using UV-1201V Spectrophotometer (Shimadzu, Japan).

\section{Effects of $p H$}

$100 \mathrm{~mL}$ Erlenmeyer flasks containing $50 \mathrm{~mL}$ of freshly prepared sterile nutrient broth (Oxoid Ltd., England) with four different $\mathrm{pH}$ values ( $\mathrm{pH}$ 5.5, 6.5, 7.5 and 8.5) adjusted with $\mathrm{NaOH}$ or $\mathrm{HCl}$ were inoculated with 0.1 $\mathrm{mL}$ liquid culture of strain MPKc as mentioned above. Flasks were incubated in an incubator shaker (New Brunswick Scientific, USA) at $30^{\circ} \mathrm{C}$ and $150 \mathrm{rpm}$. Each $\mathrm{pH}$ treatment was in duplicate. Four flasks containing non-inoculated sterile nutrient broth with four different $\mathrm{pH}$ values were used as blank controls. During the experimental period, $\mathrm{OD}_{600}$ values for all flasks were measured with UV-1201V Spectrophotometer (Shimadzu, Japan).

\section{Effects of Salinity}

Nutrient broth (Oxoid Ltd., England) with different salinity $(2.5,5,10,15,20$ and 30\%) were prepared by mixing with equal amount of distilled water and appropriate amount of analytical grade $\mathrm{NaCl}$ before autoclaving. Then, $0.1 \mathrm{~mL}$ liquid culture of strain MPKc was added into each flask containing $50 \mathrm{~mL}$ sterile nutrient broth of different salinity prepared as mentioned above. Flasks were incubated in an incubator shaker (New Brunswick Scientific, USA) at $30^{\circ} \mathrm{C}$ and $150 \mathrm{rpm}$. Non-inoculated blank controls were also prepared. The experimental set up included duplicate for each treatment. During the experimental period, $\mathrm{OD}_{600}$ values for all flasks were measured with UV1201V Spectrophotometer (Shimadzu, Japan).

\section{Analysis of Growth Data with the Gompertz Model}

The Gompertz model (Equation 1), which was found to be the most robust model to fit the bacterial growth data and easy to use ${ }^{[33]}$ among many developed models for describing the bacterial growth curve ${ }^{[34,35]}$, was applied in the calculation of three parameters, the specific growth rate $\left(\mu_{m}\right)$, lag time $(\lambda)$ and maximum biomass reached $(A)$, during the bacterial growth under different studied conditions as described elsewhere $^{[21,36]}$.

$$
X=A \exp \left\{-\exp \left[\frac{\mu_{m} e}{A}(\lambda-t)+1\right]\right\}
$$

where $X$ is the biomass concentration; $t$ is the time of incubation (hour); $\mu_{m}$ is the maxmium specific growth rate (hour ${ }^{-1}$ ); $A$ is the maximum biomass reached; $\lambda$ is the lag time (hour); $e$ is a constant, 2.718281828. The above nonlinear equation was used to fit the biomass accumulation data using nonlinear least square regression method. All data analysis was performed using Matlab 6.0 with Optimization Toolbox 2.1 (The Mathworks Inc, 2000) for minimizing the residual sum of squares (RSS) with Levenberg-Marquardt algorithm. Levenberg-Marquardt algorithm has been successfully tested on a large number of nonlinear problems and has proved to be more robust than the Gauss-Newton method and iteratively more efficient than an unconstrained method. The R-square value $\left(\mathrm{R}^{2}\right)$ and the residual sum of squares (RSS) are indices indicating 
how fit the model to the experimental data.

\section{The Plasmid DNA}

Strain MPKc was also screened for the existence of plasmid. $2 \mathrm{~mL}$ of the liquid culture of strain MPKc grown in nutrient broth medium (Oxoid Ltd., England) incubated in an incubator shaker (New Brunswick Scientific, USA) at $30^{\circ} \mathrm{C}$ and $150 \mathrm{rpm}$ for 48 hours was harvested by centrifuging at $12000 \mathrm{rpm}$ for $3 \mathrm{~min}$ and then discarding the supernatant. The plasmid DNA was then prepared by following the protocol modified from the one described by Sambrook and Russell ${ }^{[30]}$.

Firstly, the bacterial pellet was re-suspended in $100 \mu \mathrm{L}$ of ice-cold Solution I (50 mM glucose, $25 \mathrm{Mm}$ Tris· $\mathrm{Cl}$ at $\mathrm{pH} 8.0$ and $10 \mathrm{Mm}$ EDTA at $\mathrm{pH} 8.0$ ) by vigorous vortexing. The tube was inverted gently for several times after the addition of $200 \mu \mathrm{L}$ of freshly prepared Solution II (0.2 M NaOH and 1\% SDS) before being stored in an ice-bath. $150 \mu \mathrm{L}$ of ice-cold Solution III (60 $\mathrm{mL}$ of $5 \mathrm{M}$ potassium acetate, $11.5 \mathrm{~mL}$ of glacial acetic acid and $28.5 \mathrm{~mL}$ of distilled water) was introduced. After the tube was kept in the ice-bath for 4 min, it was centrifuged at $14000 \mathrm{rpm}$ for $15 \mathrm{~min}$ and the supernatant was transferred into a new centrifuge tube. The double-stranded DNA in the supernatant was precipitated with 0.6 volumes of propan-2-ol at room temperature by vortexing. The tube was air-blow dried after centrifuging $(5 \mathrm{~min} \times 12000 \mathrm{rpm})$ and carefully discarding the supernatant. Afterwards, the nucleic acid was re-dissolved in $50 \mu \mathrm{L}$ of TE ( $\mathrm{pH} 8.0$ ). The resulting DNA preparation was then examined by electrophoresis using $0.8 \%$ agrose gel consisting of the gel buffer ( $40 \mathrm{mM}$ Tris-Acetate and $1 \mathrm{mM}$ Ethylenediaminetetraacetic acid, EDTA) and $0.5 \mu \mathrm{g} / \mathrm{mL}$ Ethidium Bromide (EtBr).

The extraction and preparation of plasmid from strain MPKc and the electrophoresis for the resulting DNA preparation were conducted for the second time to further confirm the negative results of plasmid in strain MPKc. In parallel, plasmids were extracted successfully from plasmid-positive bacteria.

\section{Degradation of 2-methylindole}

The experiment was carried out in $250 \mathrm{~mL}$ Erlenmeyer flasks containing $100 \mathrm{~mL}$ of pre-sterilized MSM as described and $80 \mu \mathrm{M}$ 2-methylindole (Acros Organics, USA, purity, 98\%). The $0.1 \mathrm{~mL}$ sterile 2-methylindole solution added to each flask was prepared by firstly dissolving 2-methylindole solute (Acros Organics,
USA, purity, 98\%) in 1mL HPLC grade methanol and then passing through a $0.2 \mu \mathrm{m}$-pore-size cellulose acetate membrane syringe filter (IWAKI Glass, Japan). This experiment included two treatments, with the inoculation of active strain MPKc and autoclave-killed (inactivated) strain MPKc respectively, in duplicate, and one control without inoculation. For the treatment with the inoculation of active strain MPKc, $0.1 \mathrm{~mL}$ of culture of strain MPKc grown in nutrient broth medium (Oxoid Ltd., England) in a shaker incubator (New Brunswick Scientific, USA) at $150 \mathrm{rpm}$ and 30 $\pm 0.5^{\circ} \mathrm{C}$ for 48 hours was used as inoculum for each flask. For the treatment with the inoculation of inactivated strain MPKc, $1 \mathrm{~mL}$ of the culture of live strain MPKc mentioned above was autoclaved for $20 \mathrm{~min}$ and then $0.1 \mathrm{~mL}$ of the autoclaved culture was then used as the inoculum for each flask. All flasks were incubated in an incubator shaker (New Brunswick Scientific, USA) at $150 \mathrm{rpm}$ and $30 \pm 0.5^{\circ} \mathrm{C}$.

During the experiment, the change in the concentration of 2-methylindole in the flasks was monitored by withdrawing $1.0 \mathrm{~mL}$ of aliquot from each Erlenmeyer flasks at daily intervals and filtering through $0.2 \mu \mathrm{m}$-pore size cellulose acetate membrane syringe filter (IWAKI Glass, Japan). All samples were quantified by external standard methods using High-Performance Liquid Chromatography (HPLC) (Agilent 1100 series, Agilent Technologies) as described below immediately after sampling.

\section{Analysis of Substrate Compound}

The filtrates of samples were quantified by using HighPerformance Liquid Chromatograph (HPLC) system (Agilent 1100 series, Agilent Technologies) consisting of a quaternary low-pressure degasser, a quaternary high-pressure pump, a model 7725i manual sample injector with a $20 \mu \mathrm{L}$ sample loop, and diode array and multiple wavelength detectors. Separation of 2-methylindole was accomplished by using a $4.6 \times 150 \mathrm{~mm}$ Eclipse 5- $\mu \mathrm{m}$ XDB-C8 reversed-phase liquid chromatography column. A mixture of methanol and water (60:40, vol/vol) delivered at a flow rate of $1 \mathrm{~mL} \mathrm{~min}^{-1}$ was used as a mobile phase. The total dilution time for each sample was approximately $6 \mathrm{~min}$. The 2-methylindole in samples was quantified by external standards method at wavelength of $270 \mathrm{~nm}$. The calibration curve was linear for 2-methylindole (Acros Organics, USA, purity, 98\%) in the range from $0 \mu \mathrm{M}$ to $1000 \mu \mathrm{M}\left(\mathrm{R}^{2}=0.99996\right)$. The UV-visible spectra were recorded at identical retention time to confirm the 
identification of the compound.

\section{Results and Discussion}

\subsection{Isolation of Microorganism}

Based on the morphology of bacterial colony visually and cells microscopically, a total of 29 different bacterial isolates were obtained from the enrichment cultures. The isolate, strain MPKc, capable of degrading 2-methylindole, was selected from them for subsequent investigation in this study because of its most effectiveness.

\subsection{Identification of Strain MPKc}

Under light microscope, cells of strain MPKc appeared as rods in singly and mainly in pairs and chains. From the scanning electron micrograph (Figure 1A), the size of the cells of strain MPKc were $0.4-0.6 \mu \mathrm{m}$ in width and 1.0-2.2 $\mu \mathrm{m}$ in length and the extracellular polysaccharides, which looks like fibers on the surface of cells, could also be seen. They were motile. Spores were not observed. Strain MPKc was Gram-negative. The transmission electron micrograph (Figure 1B) also showed the cells of strain MPKc possessed a typical Gram-negative cell wall structure.

Based on the full sequence (1495 nucleotides) of the 16S rRNA gene of strain MPKc, a phylogenetic tree was constructed by comparing the $16 \mathrm{~S}$ rDNA sequence of strain MPKc and that of closely related sequences deposited in GenBank using neighbour-join- ing method ${ }^{[31]}$ (Figure 2). The nearest phylogenetic neighbour of strain MPKc was a bacterium (sequence similarity 100\%) with the accession number, AB049763, in the GenBank. Although a proposed name for that bacterial species has been deposited in the GenBank, none of the paper for its valid name and any information about that species have been published. Besides the mentioned, unpublished one (sequence accession number AB049763, similarity 100\%) and the uncultured bacterial clone PL-33B2 (sequence accession number AY570620, similarity 95\%), it was mostly closely related to Azoarcus evansii (sequence accession number X77679, similarity 94\%), suggesting strain MPKc should belong to the family Rhodocyclaceae in the $\beta$-subclass of the Proteobacteria. However, such low sequence similarity suggests that the isolate strain MPKc should be assigned as a novel bacterium, at least, at the species level.

\subsection{Physiological and Biochemical Characteristics}

The physiological and biochemical characteristics of strain MPKc were summarized in Table 1. Strain MPKc was an aerobic bacterium and gave positive results to the oxidase test. Physiological tests revealed that the isolate strain MPKc showed the following activities. Neither indole production from tryptophan nor hydrogen sulfide production from thiosulfate was observed; glucose fermentation; arginine dihyrolase; urease; $\beta$-glucosidase, protease and $\beta$-galactosidase were negative. Strain MPKc reduced nitrates to nitrogen. Strain
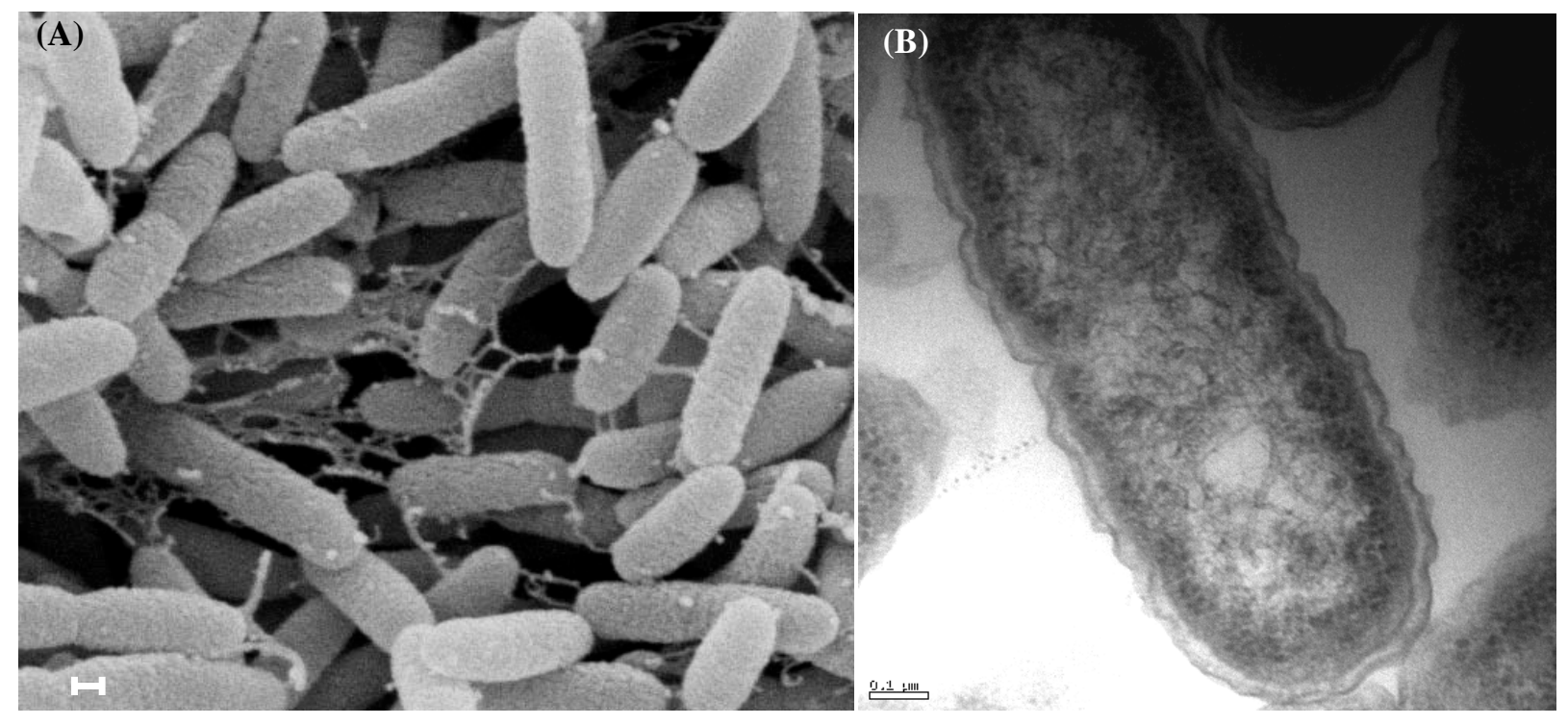

Figure 1. (A) A scanning electron micrograph of strain MPKc on a membrane filter, Bar , $200 \mathrm{~nm}$. (B) A transmission electron micrograph of strain MPKc cells showing the typical cell wall structure of Gram-negative bacteria. Bar, $0.1 \mu \mathrm{m}$. 


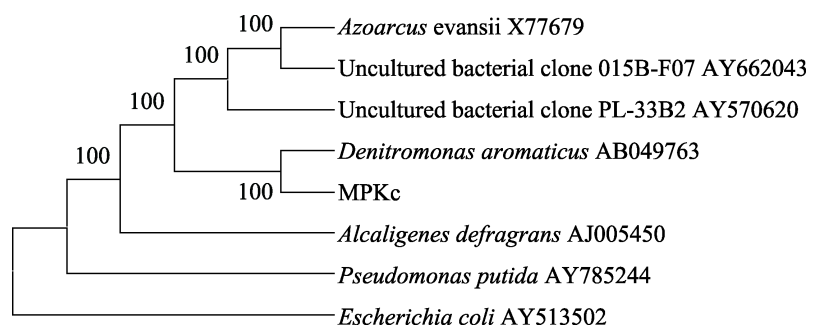

Figure 2. Phylogenetic tree of strain MPKc capable of degrading 2-methylindole isolated from sediment of Inner Deep Bay Ramsar Site of Hong Kong and related microorganisms based on their 16S rDNA sequences. Bootstrap frequency values are given at branching points of interest.

Table 1. Biochemical characteristics of the isolated strain for degradation of 2-methylindole

\begin{tabular}{|c|c|}
\hline Characteristics & Responses \\
\hline Nutrient agar colonies & Positive \\
\hline Nitrate reduction to nitrogen & Positive \\
\hline Indole production & Negative \\
\hline Acidification & Negative \\
\hline Arginine dihydrolase & Negative \\
\hline Urease & Negative \\
\hline Hydrolysis ( $\beta$-glucosidase) & Negative \\
\hline Hydrolysis (protease) & Negative \\
\hline$\beta$-galactosidase & Negative \\
\hline Hydrogen sulfide production & Negative \\
\hline Oxidase test & Positive \\
\hline \multirow[t]{3}{*}{$\begin{array}{l}\text { Utilization of carbon com- } \\
\text { pounds }\end{array}$} & $\begin{array}{l}\text { Grown on adipic acid, malate, citrate } \\
\text { and phenylacetic acid }\end{array}$ \\
\hline & $\begin{array}{l}\text { Very weak growth on glucose, arabinose, } \\
\text { mannose, mannitol, maltose, gluconate } \\
\text { and N-acetyl-glucosamine }\end{array}$ \\
\hline & No growth on capric acid \\
\hline Oxygen demand & Aerobic \\
\hline
\end{tabular}

MPKc showed a wide spectrum in the utilization of various carbon sources. It grew on adipic acid, malate, citrate and phenylacetic acid, however, it only grew weakly on glucose, arabinose, mannose, mannitol, Nacetyl-glucosamine, maltose and gluconate. No growth was observed on only one carbon source, capric acid, among those tested in this study.

\subsection{More Characteristics of Strain MPKc}

Effect of Temperature, $\mathrm{pH}$ and Salinity on the Bacterial Growth

The effect of temperature, $\mathrm{pH}$ and salinity on the growth of Strain MPKc, in terms of maximum specific growth rate $\left(\mu_{m}\right)$, lag time $(\lambda)$ and max imum biomass () , is shown in Table 2 . High values of $\mathrm{R}^{2}(>0.94)$ and small values of RSS $(<0.05)$ for all data sets indicated the applicability and the robustness of the Gompertz model for data analysis in this study.

Strain MPKc was very sensitive to the temperature change. The results demonstrated an increase in specific growth rate and a decrease in lag time of strain MPKc from low temperature, $15^{\circ} \mathrm{C}$, to high temperature, $30^{\circ} \mathrm{C}$. However, the maximum specific growth rate at $40^{\circ} \mathrm{C}$ declined drastically. Strain MPKc showed optimal growth at $30^{\circ} \mathrm{C}$ with the highest specific growth rate among four tested temperature treatments and a shorter lag time compared with that at $22^{\circ} \mathrm{C}$. Although the lag time for strain MPKc was shortest, among all four temperature treatments, at $40^{\circ} \mathrm{C}$, strain MPKc could only grow slowly $\left(0.0123 \mathrm{hr}^{-1}\right)$ and could not reach the maximum biomass as high as those at other temperatures. It is not surprising that strain MPKc showed almost lowest specific growth rate and the longest lag time, among all four temperature treatments, at $15^{\circ} \mathrm{C}$ because of the low enzyme activity as expected.

Concerning the growth of strain MPKc at different $\mathrm{pH}$, although the specific growth rates of strain MPKc were similar at $\mathrm{pH}$ 5.5, 6.5 and 7.5, its lag phase at $\mathrm{pH}$ 5.5 was nine hours longer than that at $\mathrm{pH} 6.5$ and 7.5, indicating that strain MPKc was more sensitive to lower $\mathrm{pH}$. Therefore, $\mathrm{pH} 5.5$ was not an optimum $\mathrm{pH}$ for the growth of strain MPKc. The shortest lag time and the highest specific growth rate of strain MPKc at both $\mathrm{pH} 6.5$ and 7.5 among four $\mathrm{pH}$ treatments demonstrated that strain MPKc grew optimally at $\mathrm{pH}$ 6.5-7.5. Furthermore, the strain MPKc could grow up to $\mathrm{pH} 9.5$, indicating that the hydrogen ion concentration at pH 9.5 was too high that limited the activity of enzyme with which the bacterium could synthesize new protoplasm.

Besides temperature and $\mathrm{pH}$, salinity is also a significant parameter in affecting bacterial growth in relation to the environment where this bacterium was isolated. Strain MPKc preferred to grow at relatively low salinity. Since strain MPKc possessing similar specific growth rate $\left(0.05 \mathrm{hr}^{-1}\right)$ at salinity $5 \%$ and $10 \%$, optimal growth was achieved at around salinity $5 \%$ to salinity $10 \%$ even though its lag time at $5 \%$ was slightly shorter than that at $10 \%$. Lower $\mu_{m}$ of strain MPKc and its longer $\lambda$ comparing with other salinity treatments (2.5, 5, 10 and 15\%) demonstrated that the salinity higher than $20 \%$ started to show significant negative effect on the growth of strain MPKc. 
Table 2. Specific growth rate $\left(\mu_{\mathrm{m}}\right)$, lag time $(\lambda)$ and maximum biomass yield $(A)$ of the isolate strain MPKc under different temperature, $\mathrm{pH}$ and salinity using the Gompertz model

\begin{tabular}{|c|c|c|c|c|c|}
\hline & Specific growth rate & Lag time & Maximum biomass & $\mathrm{R}^{2}$ & RSS \\
\hline & $\mu_{\mathrm{m}} \pm \mathrm{SD}\left(\right.$ hour $\left.^{-1}\right)$ & $\lambda \pm \mathrm{SD}$ (hour) & $A \pm \mathrm{SD}\left(\mathrm{OD}_{600}\right)$ & & \\
\hline \multicolumn{6}{|c|}{ Temperature $\left({ }^{\circ} \mathrm{C}\right)$} \\
\hline 15 & $0.0165 \pm 0.0001$ & $42.5737 \pm 1.4368$ & $0.8342 \pm 0.0291$ & 0.9890 & 0.0196 \\
\hline 22 & $0.0571 \pm 0.0016$ & $18.5335 \pm 0.1241$ & $0.7126 \pm 0.0069$ & 0.9783 & 0.0459 \\
\hline 30 & $0.1029 \pm 0.0028$ & $11.0003 \pm 0.0285$ & $0.6835 \pm 0.0029$ & 0.9926 & 0.0195 \\
\hline 40 & $0.0123 \pm 0.0050$ & $3.6258 \pm 3.8365$ & $0.5920 \pm 0.0666$ & 0.9924 & 0.0061 \\
\hline \multicolumn{6}{|l|}{ pH } \\
\hline 5.5 & $0.1012 \pm 0.0040$ & $18.8289 \pm 2.0838$ & $0.6911 \pm 0.0151$ & 0.9936 & 0.0191 \\
\hline 6.5 & $0.1042 \pm 0.0038$ & $11.0502 \pm 0.0431$ & $0.6915 \pm 0.0023$ & 0.9906 & 0.0245 \\
\hline 7.5 & $0.0989 \pm 0.0073$ & $10.9688 \pm 0.0733$ & $0.6787 \pm 0.0102$ & 0.9907 & 0.0231 \\
\hline 8.5 & $0.0123 \pm 0.0008$ & $14.8178 \pm 0.0226$ & $0.5987 \pm 0.0173$ & 0.9825 & 0.0240 \\
\hline 9.5 & ND & $>70$ hrs* & 0.0000 & ND & ND \\
\hline \multicolumn{6}{|c|}{ Salinity (\%) } \\
\hline 2.5 & $0.0385 \pm 0.0027$ & $7.2814 \pm 0.2194$ & $0.3933 \pm 0.0105$ & 0.9690 & 0.0193 \\
\hline 5 & $0.0524 \pm 0.0005$ & $7.4277 \pm 0.0824$ & $0.4071 \pm 0.0004$ & 0.9640 & 0.0252 \\
\hline 10 & $0.0525 \pm 0.0003$ & $8.2427 \pm 0.1867$ & $0.4129 \pm 0.0014$ & 0.9561 & 0.0346 \\
\hline 15 & $0.0418 \pm 0.0032$ & $8.9589 \pm 0.1783$ & $0.4082 \pm 0.0050$ & 0.9672 & 0.0274 \\
\hline 20 & $0.0200 \pm 0.0007$ & $10.0419 \pm 0.6322$ & $0.3292 \pm 0.0503$ & 0.9736 & 0.0080 \\
\hline 30 & $0.0077 \pm 0.0008$ & $18.2509 \pm 0.4459$ & $0.4163 \pm 0.0652$ & 0.9427 & 0.0163 \\
\hline
\end{tabular}

* No bacterial growth observed during the whole period of experiment ND, no data available (below detection limit)

SD, standard deviation of 2 replicates

The results also showed that salinity has less effect on the maximum biomass reached by strain MPKc when compared with temperature and salinity treatments.

\section{Existence of Plasmid in Strain MPKc}

Plasmids are extrachromosomal molecules of DNA in the size from $1 \mathrm{~kb}$ to more than $200 \mathrm{~kb}$. They have been found in a wide variety of bacterial species and have been proved to be involved in various functions, including resistance to and production of antibiotics, degradation of complex organic compounds, and production of colicins, enterotoxins, and restriction and modification enzymes ${ }^{[30]}$. Recently, cryptic plasmids have been isolated from Vibrio spp. isolated from Mai Po Nature Reserve ${ }^{[18,21]}$. Because of this, it was important to investigate if plasmid was in strain MPKc. However, no plasmids was detected in this strain MPKc, suggesting that the functions of this strain were much more persistent because they did not rely on genes of plasmids for coding those enzyme.

\section{Biodegradation of 2-methylindole}

Initial $80 \mu \mathrm{M}$ of 2-methylindole were completely degraded by the bacterial isolate strain MPKc in 7 days with 2-methylindole as the sole carbon source of carbon and energy (Figure 3). In contrast, there was no significant change in the concentration of 2-methylindole in sterilized controls during the whole experiments, indicating that the degradation of 2-methylindole due to natural hydrolysis and photolysis was negligible (Figure 3). Moreover, the constant concentration of

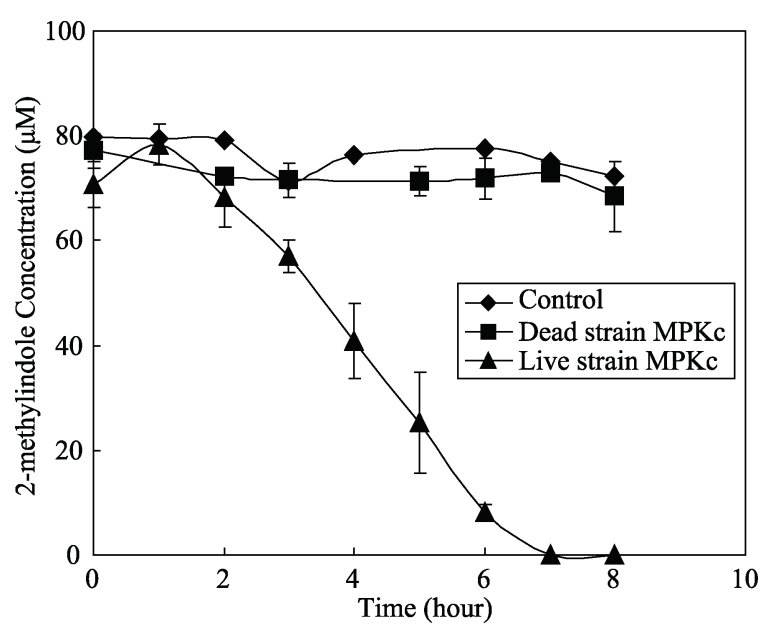

Figure 3. Degradation of 2-methylindole by the bacterial isolate strain MPKc isolated from sediment of Inner Deep Bay Ramsar Site of Hong Kong under aerobic conditions. Bar indicated standard deviation of duplicate. 
2-methylindole in treatments inoculated with autoclave-killed culture of strain MPKc during the whole experiments further confirmed that the disappearance of 2-methylindole in treatments inoculated with live bacterial culture was not due to the adsorption on the bacterial cells (Figure 3).

Up to now, only Gu and Berry ${ }^{[11]}$, Johansen et al. ${ }^{[12]}$ and $\mathrm{Gu}$ et al. $^{[7]}$ have studied the biodegradation of 1-methylindole and 2-methylindole. Neither 1-methylindole nor 2-methylindole was demonstrated to be biodegradable under methanogenic conditions ${ }^{[7,11]}$ and sulfate-reducing conditions ${ }^{[7,12]}$. It has been suggested that the methyl-group, which is an electron-donating substituent group, located at either 1- or 2- position would stabilize the indolium ion through direct inductive effects, leading to the inhibition of the attack of hydroxylation enzymes of bacteria stereochemically ${ }^{[7,11]}$. This study demonstrated that 2-methylindole could be degraded by strain MPKc at a low concentration. However, because of the high toxicity of 2-methylindole, strain MPKc could not tolerate high concentration of 2-methylindole. Less than 8\% 2-methylindole disappeared within 8 days when the initial concentration of 2-methylindole was $0.3 \mathrm{mM}$ (data not shown). Furthermore, since no plasmid DNA was found in strain MPKc as mentioned above, the degradation ability of strain MPKc for 2-methylindole should not be regarded as transferable metabolic ability under the selection pressure.

Biochemical mechanisms of indole degradation has been elucidated under strictly anaerobic conditions. Both methanogenic and sulfate-reducing conditions results in similar reaction mechanisms, mostly through initial hydroxylation and then dehydrogenation to introduce one oxygen atom onto the indolic substrate $^{[7,11-13]}$. In contrast, little information is available for aerobic conditions. Given the fact that degradation reaction on heterocyclic aromatic compounds is always near the heteroatom through hydroxylation ${ }^{[37]}$, the proposed biochemical pathway for 2-methylindole degradation by MPKc should be either at 3-position or oxidation of the methyl group at 2-position, the latter is more likely to be mediated by a monooxygenase if such reaction can be taken place (Figure 4).

\section{Conclusion}

In conclusion, the bacterial isolate, strain MPKc, isolated from the mudflat sediment, was involved in aerobic degradation of 2-methylindole. This study is the first report demonstrating that 2-methylindole was

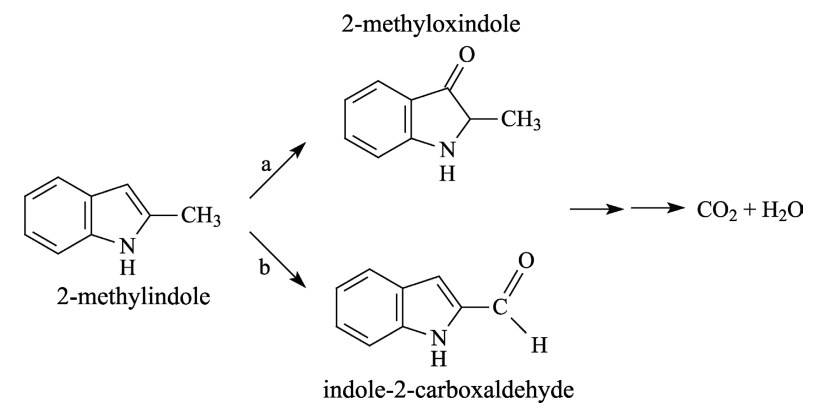

Figure 4. Proposed biochemical pathways for degradation of 2-methylindole by strain MPKc through oxidation of either (a) C-3 position or (b) the methyl group at 2-position.

biodegradable so far. Strain MPKc should be considered as a new bacterium, at least, to the species level based on 16S rDNA sequencing. Strain MPKc did not have plasmid DNA and its optimal growth occurred at $30^{\circ} \mathrm{C}$, pH 6.5-7.5 and salinity 5-10\%.

\section{Conflict of Interest and Funding}

No conflict of interest has been reported by the authors.

\section{References}

1. Dailey N S, 1981, Process effluents: quantities and control technologies, in Environmental, Health, and Control Aspects of Coal Conversion: An Information Overview, vol 1. Ann Arbor Science Publishers, Michigan: 11-57.

2. Grob K and Voellmin J A, 1970, GC-MS analysis of the 'semi-volatiles' of cigarette smoke. Journal of Chromatographic Science, vol.8: 218-220.

http://dx.doi.org/10.1093/chromsci/8.4.218.

3. Bergeim O, 1917, The determination of fecal indole. The Journal of Biological Chemistry, vol.32: 17-22.

4. Anderson G M, 1975, Quantitation of tryptophan metabolities in rat faces by thin-layer chromatography. Journal of Chromatography, vol.105(2): 323-328. http://dx.doi.org/10.1016/S0021-9673(01)82261-5.

5. Katritzky A R, Rees C W and Scriven E F V, (eds) 1996, Comprehensive Heterocyclic Chemistry II: Review of the Literature 1982-1995: The Structure, Reactions, Synthesis and Uses of Heterocyclic Compounds. Elsevier Science, Oxford: 16-17.

6. Fetzner S, 1998, Bacterial degradation of pyridine, indole, quinoline, and their derivatives under different redox conditions. Applied Microbiology and Biotechnology, vol.49(3): 237-250. http://dx.doi.org/10.1007/s002530051164.

7. Gu J-D, Fan Y and Shi H, 2002, Relationship between structures of substituted indolic compounds and their degradation by marine anaerobic microorganisms. $M a-$ 
rine Pollution Bulletin, vol.45(1-12): 379-384. http://dx.doi.org/10.1016/S0025-326X(02)00091-7.

8. Wilkes D J, (eds) 1981, Animals: bioenvironmental effects, in Environmental, Health and Control Aspects of Coal Conversion - An Information Overview, Ann Arbor Science Publishers, Michigan, vol.2: 1-163.

9. Ochiai M, Wakabayashi K, Sugimura T, et al. 1986, Mutagenicities of indole and 30 derivatives after nitrite treatment. Mutation Research, vol.172(3): 189-197.

10. Sugimura T, 1982, Mutagens in cooked food, in Genetic Toxicology. Plenum, New York: 243-269.

11. Gu J-D and Berry D F, 1991, Degradation of substituted indoles by an indole-degrading methanogenic consortium. Applied and Environmental Microbiology, vol.57(9): 2622-2627.

12. Johansen S S, Licht D, Arvin E, et al. 1997, Metabolic pathways of quinoline, indole and their methylated analogs by Desulfobacterium indolicum (DSM 3383). Applied Microbiology and Biotechnology, vol.47(3): 292-300. http://dx.doi.org/ 10.1007/s002530050929.

13. Gu J-D and Berry D F, 1992, Metabolism of 3-methylindole by a methanogenic consortium. Applied and Environmental Microbiology, vol.58(8): 2667-2669.

14. Tsim S T and Lock N Y, 2002, Knowing Ramsar Wetland. Cosmos Book Ltd., Hong Kong: 6-12.

15. Kueh C S W and Chui H K, 1996, Integrated catchment mangement of Deep Bay, Hong Kong. Water Science and Technology, vol.34(12): 1-8. http:/dx.doi.org/10.1016/S0273-1223(96)00847-5.

16. Zheng G J, Lam M H W, Lam P K S, et al. 2000, Concentrations of persistent organic pollutants in surface sediments of the mudflat and mangroves at Mai Po Marches Nature Reserve, Hong Kong. Marine Pollution Bulletin, vol.40: 1210-1214.

17. Lau S S S and Chu L M, 1999, Contaminant release from sediments in a coastal wetland. Water Research, vol.33(4): 909-918. http:/dx.doi.org/10.1016/S0043-1354(98)00286-3.

18. Lai M Y, Shen P P, Zhao Z, et al. 2005, Concentrations of heavy metals in the benthic microgastropods Sermyla riqueti and Stenothyra devalis at Mai Po Inner Deep Bay Ramsar Site of Hong Kong, in Bulletin of Environmental Contamination and Toxicology. http://dx.doi.org/10.1007/s00128-005-0689-9.

19. Wang Y, 2003, Isolation and characterization of environmental Vibrio species from Mai Po Nature Reserve, thesis, Department of Ecology \& Biodiversity, The University of Hong Kong: 29-103, viewed March 31, 2015.

20. Wang Y, Leung P C, Qian P, et al. 2004, Effects of UV, $\mathrm{H}_{2} \mathrm{O}_{2}$ and $\mathrm{Fe}^{3+}$ on the growth of four environmental isolates of Aeromonas and Vibrio species from a mangrove environment. Microbes and the Environments, vol.19(2): 163-171. http://dx.doi.org/10.1264/jsme2.19.163.

21. Wang Y and Gu J-D, 2005, Influence of temperature, salinity and $\mathrm{pH}$ on the growth of environmental Aeromonas and Vibrio species isolated from Mai Po and the Inner Deep Bay Nature Reserve Ramsar Site of Hong Kong. Journal of Basic Microbiology, vol.45(1): 83-93. http://dx.doi.org/10.1002/jobm.200410446.

22. Wang Y, Leung P C and Gu J-D, 2005, Antibiotic resistance and plasmid profile of environmental isolates of Vibrio species from Mai Po Nature Reserve. Hong Kong. Ecotoxicology, vol.15(4): 371-8. http://dx.doi.org/10.1007/s10646-006-0078-0.

23. Gu J-D, Wang Y and Li J, (eds) 2004, Degradation of the endocrine-disrupting dimethyl phthalate and dimethyl isophthalate by mangrove microorganisms, in $\mathrm{Eu}$ ropean Symposium on Environmental Biotechnology, ESEB 2004. A.A. Balkema Publishers, London: 557-561.

24. Li J, Gu J-D and Pan L, 2005, Transformation of dimethyl phthalate, dimethyl isophthalate and dimethyl terephthalate by Rhodococcus rubber Sa and modeling the processes using the modified Gompertz model. International Biodeterioration \& Biodegradation, vol.55(3): 223-232.

http:/dx.doi.org/10.1016/j.ibiod.2004.12.003.

25. Li J and Gu J-D, 2005, Biodegradation of dimethyl terephthalate by Pasteurella multocida Sa follows a novel biochemical pathway. Ecotoxicology, vol.15(4): 391-397. http:/dx.doi.org/10.1007/s10646-006-0070-8.

26. Xu X-R, Li H-B and Gu J-D, 2005, Biodegradation of an endocrine-disrupting chemical di-n-butyl phthalate ester by Pseudomonas fluorescens B-1. International Biodeterioration \& Biodegradation, vol.55(1): 9-15. http://dx.doi.org/10.1016/j.ibiod.2004.05.005.

27. Benson H J, 1998, Microbiological Applications: Laboratory Manual in General Microbiology, $7^{\text {th }}$ edn, McGraw-Hill Companies, Inc., Boston.

28. Smibert R M and Krieg N R, 1994, Phenotypic characterization, in Methods for General and Molecular Bacteriology. American Society for Microbiology, Washington, D.C.: 607-654.

29. Wilson K H, Blitchington R B and Greene R C, 1990, Amplification of bacterial 16S ribosomal DNA with polymerase chain reaction. Journal of Clinical Microbiology, vol.28: 1942-1946.

30. Sambrook J and Russell D W, 2001, Molecular Cloning: A Laboratory Manual, $3^{\text {rd }}$ edn. Cold Spring Laboratory Press, United States of America.

31. Saitou N and Nei M, 1987, The neighbour-joining method: a new method for reconstructing phylogenetic trees. 
Molecular Biology and Evolution, vol.4(4): 406-425.

32. Gu J-D, Ford T E and Mitchell R, 1996, Susceptibility of electronic insulating polyimides to microbial degradation. Journal of Applied Polymer Science, vol.62(7): 1029-1034.

http://dx.doi.org/10.1002/(SICI)1097-4628(19961114)6 2:7<1029::AID-APP8>3.0.CO;2-M.

33. Zwietering $\mathrm{M} \mathrm{H}$, Jongenburger I, Rombouts $\mathrm{F} \mathrm{M}$, et al. 1990, Modeling of the bacterial growth curve. Applied and Environmental Microbiology, vol.56(6): 1875-1881.

34. Richards F J, 1959, A flexible growth function for empirical use. Journal of Experimental Botany, vol.10(2): 290-301.

http:/dx.doi.org/10.1093/jxb/10.2.290.

35. Schepers A W, Thibault J and Lacroix C, 2000, Com- parison of simple neural networks and nonlinear regression models for descriptive modeling of Lactobacillus helveticus growth in $\mathrm{pH}$-controlled batch cultures. Enzyme and Microbial Technology, vol.26(5-6): 431-445. http:/dx.doi.org/10.1016/S0141-0229(99)00183-0.

36. Fan Y, Wang Y, Qian P-Y, et al. 2004. Optimization of phthalic acid batch biodegradation and the use of modified Richards model for modelling degradation. International Biodeterioration \& Biodegradation, vol.53(1): 57-63. http://dx.doi.org/10.1016/j.ibiod.2003.10.001.

37. Wackett L P and Hershberger C D, 2001, Biocatalysis and Biodegradation - Microbial Transformation of Organic Compounds, American Society for Microbiology Press, Washington, D.C. 